\title{
Range Finding Test of Scirpus grossus on Aluminium and Iron Contaminated Soil
}

\author{
Anindita Sari Pertiwi ${ }^{1}$, Ipung Fitri Purwanti ${ }^{1}$, Bieby Voijant Tangahu ${ }^{1}$, Setyo Budi Kurniawan ${ }^{1}$
}

\begin{abstract}
High concentration metal in soil may cause pollution. Particularly for aluminium and iron in soil. Even though these substances are necessary micro-substances for plants, but if the soil has it in high concentration, it will cause more complex environmental problem. These two metals were found in high concentration in soil near the small Industry Environment that recycled aluminium in Jombang Regency, East Java. High concentration also caused soil contamination, thus treatment towards the land was needed. One of the best solutions to overcome land contamination was phytoremediation. Scirpus grossus, to date, is the most widely used wild plant which has the ability in remediating metal pollutant in soil. Before treating metal on soil, toxicity test needed to be done beforehand. Toxicity test was done using Range Finding Test (RFT) method for 7 days using reactors with each filled with $5 \mathrm{~kg}$ of soil and 4 plants. RFT was done in different concentration composition between Al:Fe. The load variation (mg/kg) of Al:Fe in the reactors were 10.000:0, 5.000:50, 500:500, 50:5.000, 0:10.000 and control reactor. The result obtained after 7 days were that Scirpus grossus plant could survive in pollution load of Al:Fe 500:500 (mg/kg) with $75 \%$ percentage of living plants.
\end{abstract}

Keywords - Aluminium, Iron, Scirpus grossus, Range Finding Test

\section{INTRODUCTION}

A luminium recycle industry in Jombang Regency, Jawa Timur, had been operating for more than 30 years. In yearly report by local environmental agency, Dinas Lingkungan Hidup Kabupaten Jombang, aluminium and iron substance was found in the ground near the area [1]. Aluminum metal itself is carcinogenic towards human [2]. Not only for human, aluminium in high concentration is also toxic towards plants [3]. Aluminium poisoning in plants are characterized by plant productivity decrease, beginning with the slowing down of root cell elongation, which in turn decrease nutrition absorbing [4]. Not like aluminium, iron is very important for growth and usually is considered as macronutrient and is responsible as energy transformation in synthesis process [5]. Even though iron is not considered toxic metal, but its interaction with toxic metal is very important. Iron has the ability to absorb a lot of elements and can participate to weaken heavy metals such as manganese, nickel, and cobalt, which can reduce absorption and translocation of iron and decrease chlorophyll amount in leaves [6], [7].

Phytoremediation can improve land and groundwater condition that have been polluted by dangerous heavy metal, radio nuclide, and organic contaminants [8]. The use of hyperaccumulator plant like Scirpus grossus is appropriate to apply. In previous [9] study, Scirpus grossus could remove aluminium and iron contaminants up to $33,3 \%$ in polluted water.

\footnotetext{
${ }^{1}$ Anindita Sari Pertiwi, Ipung Fitri Purwanti, Bieby Voijant Tangahu, and Setyo Budi Kurniawan are with Department of Department of Environmental Engineering, Institut Teknologi Sepuluh Nopember, Surabaya, 60111, Indonesia. E-mail: aninditaspertiwi@gmail.com; purwanti@enviro.its.ac.id; setyobudi.kurniawan@gmail.com.
}

In this study, artificial waste was made from salt metal of $\mathrm{AlCl} 3$ and $\mathrm{FeCl} 3$ diluted by aquadest, made in laboratory of remediation, Laboratorium Remediasi Teknik Lingkungan ITS. The aim of this study was to analyze the toxicity rate of $\mathrm{Al}$ and Fe towards Scirpus grossus and to determine if this plant can be categorized as hyperaccumulator for $\mathrm{Al}$ and Fe metals.

Range Finding Test (RFT) to determine the maximum $\mathrm{Al}$ and $\mathrm{Fe}$ concentration where the Scirpus grossus could survive without disturbing the metabolism of plants. This RFT method was the starting step of phytoremediation process.

\section{METHOD}

This study was done in laboratory scale. Metal material in this study used salt metal of $\mathrm{AlCl} 3$ dan $\mathrm{FeCl} 3$ which were produced by SAP. The first step of this study was to make $50.000 \mathrm{mg} / \mathrm{l}$ stock solution by mixing 1 liter of tap water with each metal salt based as needed (50.000 mg/l). Contaminated soil was made from the mix of $\mathrm{Al}$ and $\mathrm{Fe}$ based on each pollutant load with $5 \mathrm{~kg}$ of sieved and dried soil. The pollutant load (mg/kg) variations of $\mathrm{Al}$ and $\mathrm{Fe}$ were 10.000:0, 5.000:50, 500:500, 50:5.000 and 0:10.000.

The reactors used were $5 \mathrm{l}$ volume plastic filled with $5 \mathrm{~kg}$ of soil as plantation media as seen in Figure 1.

Each reactor contained 4 Scirpus grossus. The amount of plant in the reactor was counted based on its specific density. Scirpus grossus was taken from the second generation with the same age. Acclimatization was done for a week to let the plants adapt. Observation for this study was done for 7 days by observing physical change on plants and compare it with control. 


\section{RESULTS AND DISCUSSION}

This research has some parameters, they were $\mathrm{pH}$, temperature and moisture. As seen in Table 1, the activity plants in absorbing nutrients in soil is also influenced by the ideal $\mathrm{pH}$. The optimum $\mathrm{pH}$ for Scirpus grossus 4-9 [10], so that the $\mathrm{pH}$ of the research reactor is still in the optimum $\mathrm{pH}$ range of plants to growth ideal.

Temperature is one of the environmental factors that affect plant growth and development. Temperature analysis in this study was conducted every 7 days. The results of the study on temperature parameters, in the S. grossus reactor ranged in temperature from 25 to $35^{\circ} \mathrm{C}$. The temperature of this reactor is still included in the optimum plant temperature, $10-38{ }^{\circ} \mathrm{C}$ [11]. The range of the reactor is still within the optimum temperature range for plants to do the ideal process, this is because plants can work to absorb nutrients optimally because they are influenced by ideal temperatures.

Moisture of reactors mostly $100 \%$, This is because the plants used in this study are aquatic plants, besides the addition of aluminum and iron contaminants in the form of a solution causes the reactor to reach a holding capacity to water. This condition that matches the holding capacity causes the reactor soil to be always saturated with water. This condition of saturation of water causes soil moisture to become high.

Scirpus grossus could survive in reactor with $\mathrm{Al}$ :Fe ration 500:500, 5.000:50, and 10.000:0 during 7 days of observation. This was proved by the percentage of living plant which reached $75-100 \%$. The documentation of living plants comparison up to day 7 can be seen in Table 2 .

Scirpus grossus which was exposed with Al:Fe 0:10.000 and 50:5.000 solution started showing color change in the first day of observation. Scirpus grossus leaves turned black, withered, and dry. The observation result was supported by previous study which stated that Fe content beyond optimal level could cause root tissue damage, necrosis, and roots blackening [12]. Physical change showed that $\mathrm{Al}$ :Fe had disrupted the metabolism process of Scirpus grossus.

TABLE 1.

ENVIRONMENTAL PARAMETERS ON 7 DAYS

\begin{tabular}{ccccc}
\hline \hline Reactor (Al:Fe) & $\mathbf{p H}$ & Temperature $\left({ }^{\circ} \mathbf{C}\right)$ & Moisture (\%) & Percentage of Living Plants (\%) \\
\hline $10.000: 0$ & $3,5-6$ & $25-30$ & 100 & 100 \\
$5.000: 50$ & $4-5$ & $25-30$ & 100 & 100 \\
$500: 500$ & $4,5-5$ & $25-30$ & 100 & 75 \\
$50: 5.000$ & $4-5$ & $26-33$ & 100 & 50 \\
0:10.000 & $4,5-5$ & $26-35$ & 100 & 0 \\
Control & $4-7$ & $25-30$ & 100 & 100 \\
\hline \hline
\end{tabular}

TABLE 2.

DAY-7 OBSERVATION OF SCIRPUS GROSSUS

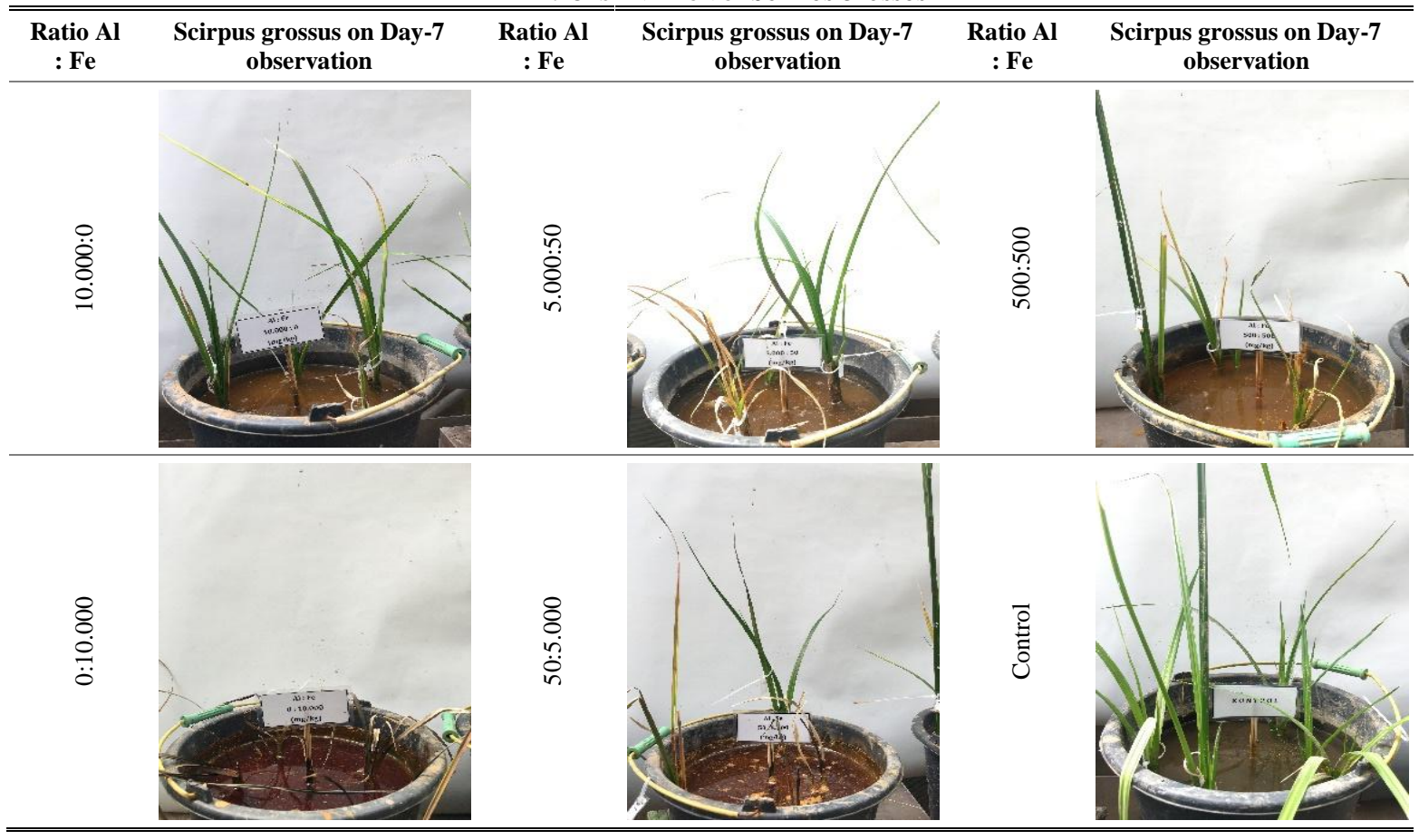




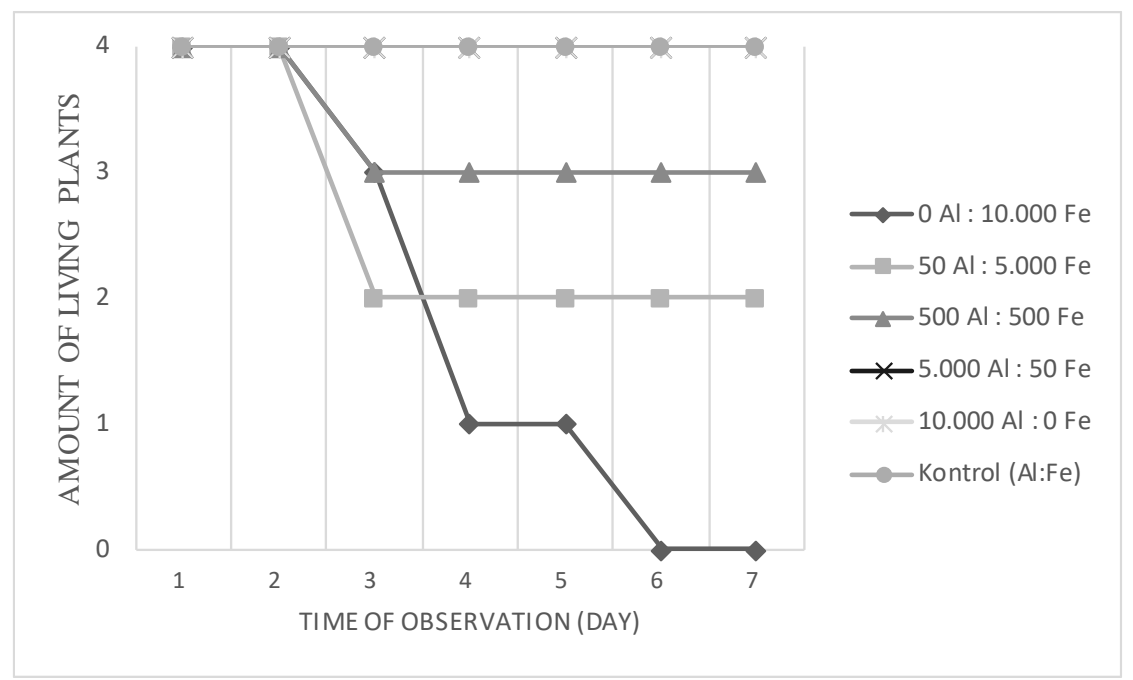

Figure 1. Surviving Plants in RFT

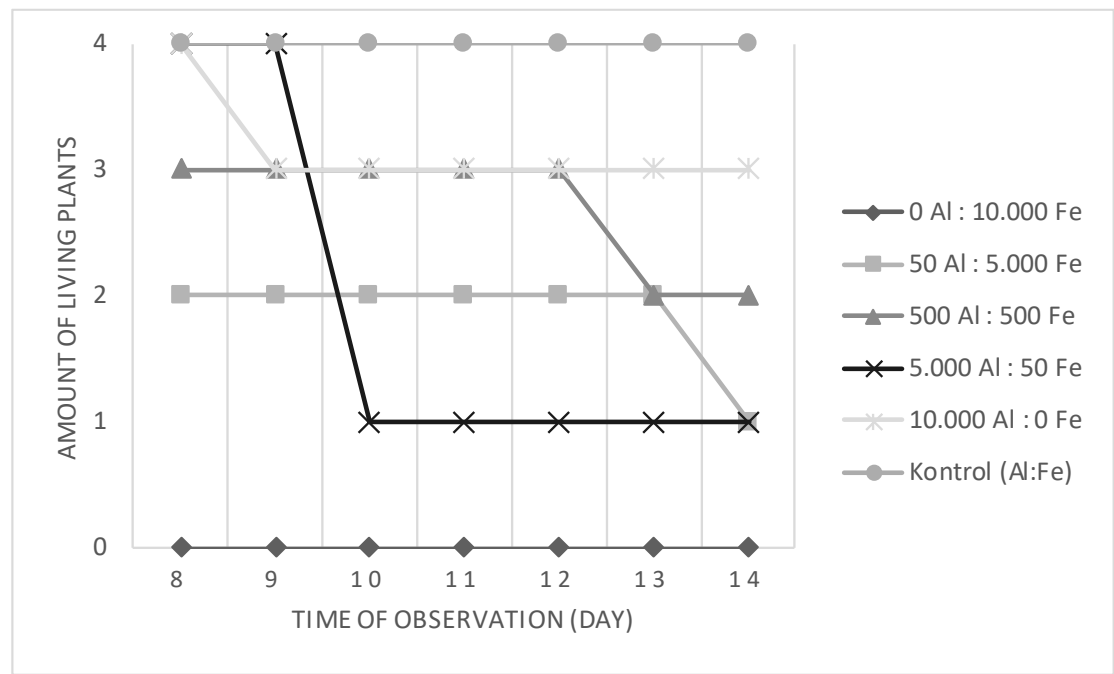

Figure 2. Prolonged RFT

The maximum pollutant load that would be used in phytoremediation should not have been disrupting plants metabolism activity. The combination of $\mathrm{Al}$ and $\mathrm{Fe}$ can cause damage in Thymallus thymallus and Salmo trutta [13] because these metals have interaction to each other. In another research [9], Scirpus grossus can remove 33\% of $\mathrm{Al}$ and $\mathrm{Fe}$ in $450 \mathrm{mg} / \mathrm{L} \mathrm{Al}$ and $150 \mathrm{mg} / \mathrm{L} \mathrm{Fe}$ in waste water. Aluminium in $200-400 \mathrm{mg} / \mathrm{kg}$ can disturb the assimilation of plants [14], wheter iron in $1.000 \mathrm{mg} / \mathrm{kg}$ can disturb the metabolic proccess in plants [15].

The pollutant load in this study could be analyzed based on plant death rate in one reactor during observation days. Reactor with Al:Fe 0:10.000 started to show changes in the $3^{\text {rd }}$ day of observation and plants died in day 6. For $\mathrm{Al}: \mathrm{Fe}$ 50:5.000, 2 plants died in the $3^{\text {rd }}$ day of observation. Al:Fe 500:500 showed death of 1 plant on the $3^{\text {rd }}$ day. The Al:Fe reactor itself only showed change in the $7^{\text {th }}$ day with the death of 1 plant, leaving 3 living plants. The result percentage of living plants for 7 days observation on RFT can be seen on Figure 1.

Based on the above table 1, the surviving plants after 7 days observation were in 10.000:0, 50:5000, 500:500, $5.000: 50$, and control reactors. In the $7^{\text {th }}$ day of observation.
The living percentage for each reactor were $0 \%$ for $0: 10.000,50 \%$ for $50: 5.000,75 \%$ for $500: 500$, and $100 \%$ for 5.000:50 and 10.000:0 which were compared with control reactor (0:0).

To prove that the maximum $\mathrm{Al}$ and $\mathrm{Fe}$ can be maintained by Scirpus grossus at $500 \mathrm{mg} / \mathrm{kg} \mathrm{Al}$ and $500 \mathrm{mg} / \mathrm{kg} \mathrm{Fe}$, the prolonged RFT has been done. As seen on Figure 2, confirmed that 500:500 was the maximum Scirpus grossus can endured because the $14^{\text {th }}$ day of observations, the percentage of living plants in this reactor was about $50 \%$ and the plants were in the best condition compare to all the ractors with $\mathrm{Al}: \mathrm{Fe}$ contaminants that have less percentage of living plants.

\section{CONCLUSION}

In this study the toxicity test result stated that Scirpus grossus can survive $75 \%$ in 500:500 reactor, and 100\% for 5.000:50 reactor and 10.000:0 which were compared with control reactor (0 mg/kg Al : $0 \mathrm{mg} / \mathrm{kg} \mathrm{Fe}$ ).

Based on the 7 days observation toward 6 reactors, it could be inferred that the toxicity rate between aluminium and iron were different. Iron had higher toxicity than aluminium, proven by the death of plant with $0 \mathrm{mg} / \mathrm{kg}$ 
aluminium and $10.000 \mathrm{mg} / \mathrm{kg}$ iron load with $0 \%$ survival rate, compared with $10.000 \mathrm{mg} / \mathrm{kg}$ aluminium and $0 \mathrm{mg} / \mathrm{kg}$ iron pollutant load.

\section{REFERENCES}

[1] PEMDA Kabupaten Jombang, "Laporan Informasi Kinerja Pengelolaan Lingkungan Hidup Daerah (LIKPLHD) Kabupaten Jombang tahun 2016,” Jombang, 2016.

[2] IARC Monographs, "List of classifications, Volumes 1-123 IARC," (International Agency for Reasearch on Cancer) IARC Monographs. [Online]. Available: https://monographs.iarc.fr/listof-classifications-volumes/.

[3] D. Dent, Acid sulphate soils: a baseline for research and development. Wageningen: International Institute for Land Reclamation and Improvement/ILRI, 1986.

[4] B. Ma, L. Gao, H. Zhang, J. Cui, and Z. Shen, "Aluminum-induced oxidative stress and changes in antioxidant defenses in the roots of rice varieties differing in Al tolerance," Plant Cell Rep., vol. 31, no. 4, pp. 687-696, Apr. 2012.

[5] L. M. Thompson and F. R. Troeh, Soils and soil fertility, 3d ed. New York: McGraw-Hill, 1973.

[6] I. Bodek, W. J. Lyman, W. F. Reehl, and D. H. Rosenblatt, Environmental inorganic chemistry: properties, processes, and estimation methods. New York-Oxford: Pergamon Press, 1988.

[7] A. Kabata-Pendias and H. Pendias, Trace elements in soils and plants, 2nd ed. Boca Raton, Florida: CRC Press, 1992.
[8] J. L. Schnoor, L. A. Light, S. C. McCutcheon, N. L. Wolfe, and L. H. Carreia, "Phytoremediation of organic and nutrient contaminants," Environ. Sci. Technol., vol. 29, no. 7, p. 318A323A, Jul. 1995.

[9] N. I. Ismail, S. R. S. Abdullah, M. Idris, H. A. Hasan, N. H. AL Sbani, and O. H. Jehawi, "Tolerance and Survival of Scirpus grossus and Lepironia articulata in Synthetic Mining Wastewater," J. Environ. Sci. Technol., vol. 8, no. 5, pp. 232-237, May 2015.

[10] R. W. Crites, E. J. Middlebrooks, R. K. Bastian, and S. C. Reed, Natural wastewater treatment systems, Second edition. Boca Raton, Florida: CRC Press, 2014.

[11] R. Firmansyah, Mudah dan aktif belajar biologi 3. Jakarta: Pusat Perbukuan, Departemen Pendidikan Nasional, 2009.

[12] P. Laan, A. Smolders, and C. W. P. M. Blom, "The relative importance of anaerobiosis and high iron levels in the flood tolerance ofRumex species,” Plant Soil, vol. 136, no. 2, pp. 153161, Oct. 1991.

[13] P. J. Vuorinen, M. Keinänen, S. Peuranen, and C. Tigerstedt, "Effects of iron, aluminium, dissolved humic material and acidity on grayling (Thymallus thymallus) in laboratory exposures, and a comparison of sensitivity with brown trout (Salmo trutta)," Boreal Environ. Res., vol. 3, pp. 405-419, 1999.

[14] P. Liu, Y. S. Yang, G. Xu, S. Guo, X. Zheng, and M. Wang, "Physiological responses of four herbaceous plants to aluminum stress in South China," Front. Biol. China, vol. 1, no. 3, pp. 295302, Sep. 2006.

[15] E. L. Connolly and M. Guerinot, "Iron stress in plants," Genome Biol., vol. 3, no. 8, p. reviews1024.1-4, Jul. 2002. 